\title{
EFFECT OF PRECEDING AND CATCH CROP WITH BORON FOLIAR APPLICATION ON YIELD AND QUALITY OF SUGAR BEET (BETA VULGARIS L.)
}

\author{
Zahera M. Attia, Amira A. El-Mehy and K. S. Badr \\ Crop Intensification Research Department, Field Crops Res. Instit., ARC, Giza, Egypt \\ Received: Apr. 15, 2018 \\ Accepted: Apr. 24, 2018
}

ABSTRACT: Two field experiments were carried out in Sers EL-Lian Agric. Res. Station, ARC, Minufiya Governorate, during 2015/2016 and 2016/2017 growing seasons, to study the effect of preceding crop (mono preceding crop) or preceding + catch crop (di preceding crops) and foliar application of boron as boric acid on yield and quality of sugar beet cv. Gloria. The experimental design was strip-plots design with three replications. Mono and di preceding crops (Maize, Maize/Fahl berseem, soybean and soybean/Fahl berseem) were allocated in horizontal plots and three boron foliar applications [(zero $\left(B_{1}\right)$ control, $0.10 \mathrm{~g} / \mathrm{L}\left(B_{2}\right)$ and $\left.0.20 \mathrm{~g} / \mathrm{L}\left(B_{3}\right)\right]$ were in vertical plots. The results can be summarized as follows:

Soil content of organic matter, available NPK and boron element were higher after di preceding crop including legume crops, soybean/fahl berseem, compared to maize as a preceding crop.

Di preceding crop had significant effect on growth, root and sugar yields ton/fed as well as Total soluble solids percentage (TSS \%), sucrose \% and purity \% in both seasons. Legumes as preceding crops for sugar beet significantly increased all studied characters, except quality characters of sugar beet compared with maize. The highest root and sugar yields/fed were obtained when sugar beet was planted after soybean/fahl berseem (32.74, 5.00 ton/fed). The same yields were obtained after soybean (31.60 and 4.88 ton/fed) as average of both seasons, with an ignored difference.

Boron application significantly affected all sugar beet characters in both seasons compared to control treatment, except number of leaves/plant in second season and purity $\%$ in the first season. Increasing boron concentration from 0 up to $0.20 \mathrm{~g} / \mathrm{L}$ caused significant increases for all sugar beet characters. Foliar application of $B_{3}(0.20 \mathrm{~g} \mathrm{~B} / L)$ achieved the highest root and sugar yields/fed followed by $B_{2}(0.10 \mathrm{~g} / \mathrm{L})$.

Sowing sugar beet after soybean/fahl berseem and boron application at $0.20 \mathrm{~g} / \mathrm{L}$, achieved the highest values for most sugar beet characters, except quality traits, compared with the lowest values gained with control following maize.

Growing fahl berseem, as catch crop, following maize and soybean increased soil fertility, maximized total cereal units by 13.46 and $11.47 \%$ and net return by 33.50 and $24.08 \%$, as average of both seasons, compared with maize and soybean as a mono preceding crop.

Key words: Preceding crop, Catch crop, Soil fertility, Boron, Sugar beet, Root yield, Sugar yield, Cereal units, Net return.

\section{INTRODUCTION}

Sugar beet is an important sugar crop not only in Egypt but also all over the world. In Egypt, contribution of sugar beet to sugar production increased largely from $2.5 \%$ in 1982 to about $48.1 \%$ of the total sugar production in 2012 (Abbas et al., 2014). Thus, it is considered the second sugar crop after sugar cane. Currently, the annual consumption of sugar in Egypt amounts to be 3.230 million tons, while the 
production of sugar yield from both sugar cane and beets is about 2.249 million tons in 2016/2017 season (SCC, 2017). Narrowing the gap between the consumption and production, could be achieved through an effective use of modern techniques by the proper choice of preceding summer crop for sugar beet and adequate boron (B) nutrition which critical for high yields and quality of crops.

Legumes as preceding crops are a potential way of increasing the available $\mathrm{N}$ supply for the following crops (Das et al., 2010), improve soil porosity and structure (Mc Callum et al., 2004), increasing soil organic matter by $\mathrm{N}$ inputs from fertilizer $\mathrm{N}$, retention of residues and N2 fixing (Shafi et al., 2010), help to increase the available $N, P$ and $K$ content of the soil (Pokhrel and Pokhrel, 2013). At harvest of soybean, the soil nutrient status was influenced by the nodulation of soybean crop (Kadam et al., 2010 and Vidyavathi et al., 2012). Legumes fix the atmospheric nitrogen and facilitate soil nutrients' circulation (Stagnari, 2017).

Sugar beet when grown after soybean crop, root yields were still greater than following maize but, less than following wheat, while sugar root quality tended to start declining when sugar beet sown after soybean (Sims, 2007). Yield and quality of sugar beet plants sowing after soybean and/or peanut significantly surpassed those after maize, sunflower and sweet sorghum which were the worst preceding crops for sugar beet (Maareg et al., 2005 and El-Mallah 2008). Ibrahim (2018) found that sugar beet preceded by soybean was superior in all studied characters, except quality traits (TSS\%, sucrose \% and purity \%) of sugar beet. Inclusion of Legumes in intensive agriculture has proven to enhance soil fertility of subsequent crops (Peoples et al., 2009 and Abdel Galil et al., 2015), increase yields, cereal units and net income (Abou-Kerisha et al., 2008, Abdel Galil et al., 2015, El-Mehy et al., 2016 and Zohry et al., 2017).

Boron as a nutrient element is very necessary for sugar beet growth and yield, it is increase the rate of sugar transport, promotes the stability and rigidity of cell wall structure and therefore, supports the shape and strength of the plant cell (Brown et al, 2002). Without boron, growth and sugar beet yield were depressed (Cooke and Scott, 1993). Allen et al. (2007) indicated that boron increased the rate of transport of sugars which are produced by photosynthesis in mature plant leaves to growing regions. Increasing boron application from 0 up to $0.25 \mathrm{~g} / \mathrm{L}$ caused an increase in root length and diameter and also sucrose $\%$ but without significant differences between 0.25 and $0.20 \mathrm{~g}$ of boron/L application (Abbas et al., 2014 and Dewedar et al., 2015). Boron increase root weight and diameter, enhance dry matter accumulation and improve quality of roots that increase sugar yield of sugar beet (AbdelMotagally 2015). Nemeata Alla et al. (2016) indicated that addition $1.5 \mathrm{Kg} / \mathrm{fed}$ gave the highest values of root dimension, yields of root, top and sugar Ifed in addition to quality traits as sucrose $\%$ followed by $1 \mathrm{Kg}$ boron/fed and the lowest values obtained with control except purity \%.

The aim of this study is to know the effect of mono and di preceding crops and foliar application of boron on root and sugar yields, quality characters of sugar beet, total cereal units and net return.

\section{MATERIALS AND METHODS}

Two field trials were conducted in the farm of Sers El-Lian Agriculture Research station, Agriculture Research Center (A.R.C.), Minufiya governorate, during 
$2015 / 2016$ and $2016 / 2017$ seasons to study the effect of preceding crop (mono preceding) or preceding + catch crop (di preceding) i.e. Maize, Maize/Fahl berseem, soybean and soybean/Fahl berseem (as preceding crops of sugar beet) and foliar application with boron as boric acid on growth, yield and its components as well as some chemical analysis of sugar beet (Beta Vulgaris L.) cv. Gloria. Some physical properties and chemical analysis according to methods described by Jackson (1973) of the experimental soil before planting preceding crops in 2015/2016 and 2016/2017 seasons are shown in Table (1).
The experimental design was stripplots design with three replications. The horizontal plots (main) were occupied by mono and di preceding crops and vertical plots (sub) were devoted for foliar application with boron. The area of each sub plot was $10.5 \mathrm{~m}^{2}$ (5 ridges $0.60 \mathrm{~m}$ in width and $3.5 \mathrm{~m}$ in length).

Each experimental included 12 treatments were as follows:

I. Mono and di preceding crops were:

1. Maize (mono preceding crop).

2. Maize / Fahl berseem (di preceding crops).

3. Soybean (mono preceding crop).

4. Soybean I Fahl berseem (di preceding crops).

Table (1): Some physical properties and chemical analysis of the experimental soil before planting preceding crops in 2015/2016 and 2016/2017 seasons.

\begin{tabular}{|c|c|c|}
\hline Seasons & $2015 / 2016$ & $2016 / 2017$ \\
\hline \multicolumn{3}{|c|}{ a. Mechanical analysis } \\
\hline Coarse sand\% & 1.27 & 1.59 \\
\hline Fine sand \% & 27.12 & 32.12 \\
\hline Silt\% & 30.90 & 27.89 \\
\hline Clay\% & 40.71 & 38.40 \\
\hline Soil texture & clay loam & clay loam \\
\hline \multicolumn{3}{|c|}{ b. Chemical analysis } \\
\hline PH & 7.80 & 7.84 \\
\hline E.C. mmohs & 1.92 & 1.57 \\
\hline $\mathrm{N} \mathrm{mg/kg}$ & 110 & 107.25 \\
\hline$P \mathrm{mg} / \mathrm{kg}$ & 27 & 26 \\
\hline $\mathrm{K} \mathrm{mg/kg}$ & 548 & 539.9 \\
\hline \multicolumn{3}{|c|}{ Soluble cations (mg/L) } \\
\hline $\mathrm{Ca}++$ & 5.80 & 2.10 \\
\hline $\mathrm{Mg}++$ & 2.30 & 1.20 \\
\hline $\mathrm{Na}+$ & 2.64 & 3.70 \\
\hline $\mathrm{K}+$ & 1.57 & 3.50 \\
\hline \multicolumn{3}{|c|}{ Soluble anions(mg/L) } \\
\hline Co3-- & - & - \\
\hline Hco3- & 3.02 & 4.20 \\
\hline CL- & 5.35 & 3.80 \\
\hline So4-- & 3.94 & 2.50 \\
\hline
\end{tabular}


II. Foliar application with boron sprayed twice at 80 and $\mathbf{1 1 0}$ days after sugar beet sowing as follows:

1. Foliar application with (water): zero, control $\left(B_{1}\right)$.

2. Foliar application with boron: $\mathbf{0 . 1 0}$ $\mathrm{g} / \mathrm{L}\left(\mathrm{B}_{2}\right)$.

3. Foliar application with boron: $\mathbf{0 . 2 0}$ g/L $\left(B_{3}\right)$.

The foliar solutions volume was to 200 L/fed conducted by hand sprayer.

Sugar beet c.v Gloria was sown in hills $20 \mathrm{~cm}$ apart, approximately $3-4$ seed balls/hill. Sugar beet seeds were sown on $12^{\text {th }}$ and $13^{\text {th }}$ of November in the first and second seasons, respectively. The plants were thinned to one plant/hill at 4 - 6 leaves stage. Phosphorus fertilizer was added during land preparation in the form of calcium superphosphate $\left(15.5 \% \mathrm{P}_{2} \mathrm{O}_{5}\right)$ at a rate of $200 \mathrm{Kg}$ /fed. Nitrogen fertilizer was added in the form of ammonium nitrate (33.5\%) at a rate of $80 \mathrm{Kg} \mathrm{N} / \mathrm{fed}$ in two equal doses just before the second and third irrigation. Potassium fertilizer was applied at a rate of $50 \mathrm{Kg} / \mathrm{fed}$ in the form of potassium sulphate $\left(48 \% \mathrm{~K}_{2} \mathrm{O}\right)$ applied in two equal doses just before the second and third irrigation. Other cultural practices were done as recommended for sugar beet plants. Planting and harvesting dates for crops in both seasons are presented in Table (2).

The following data were recorded:

I. Soil content of available NPK, organic matter and boron element:

Soil samples were collected before growing sugar beet, after harvesting preceding crops, at the depth of $0-30 \mathrm{~cm}$ in the two growing seasons. These samples were air-dried, crushed, and sieved by 2-mm sieve for the chemical analysis. These analyses were conducted in Central Laboratory, Faculty of Agriculture Ain Shams University, Egypt.

\section{Data recorded on preceding and catch crop:}

At harvest grain and straw yields of maize, seed and straw yields of soybean and fresh forage yield of fahl berseem were recorded on the basis of experimental plot area by harvesting all plants of each plot then turn to ton/ fed. The average yield of summer and catch crops (fahl berseem) in both seasons were presented in Table (3).

Table (2): Planting and harvesting dates for crops in 2015/2016 and 2016/2017 seasons.

\begin{tabular}{|c|c|c|c|c|}
\hline \multirow{2}{*}{$\begin{array}{l}\text { Planting and harvest } \\
\text { date } \\
\text { Preceding crop }\end{array}$} & \multicolumn{2}{|c|}{ 2015/2016 season } & \multicolumn{2}{|c|}{$2016 / 2017$ season } \\
\hline & $\begin{array}{c}\text { Planting } \\
\text { date }\end{array}$ & $\begin{array}{l}\text { Harvesting } \\
\text { date }\end{array}$ & Planting date & $\begin{array}{l}\text { Harvesting } \\
\text { date }\end{array}$ \\
\hline Maize cv. SC 128 & $10 / 5 / 2015$ & 2/9/2015 & $10 / 5 / 2016$ & $5 / 9 / 2016$ \\
\hline Soybean cv. Giza 111 & $15 / 5 / 2015$ & 9/9/2015 & $14 / 5 / 2016$ & $8 / 9 / 2016$ \\
\hline Berseem c.v Fahl & 11/9/2015 & 9/11/2015 & $10 / 9 / 2016$ & $10 / 11 / 2016$ \\
\hline sugar beet c.v Gloria & $12 / 11 / 2015$ & $12 / 5 / 2016$ & $13 / 11 / 2016$ & $14 / 5 / 2017$ \\
\hline
\end{tabular}

Soybean seeds were planted by using the wet (Herati) method of planting. 
Table (3): Mean yields of preceding crops in 2015/2016 and 2016/2017 seasons.

\begin{tabular}{|l|c|c|c|c|c|}
\hline \multirow{2}{*}{ Preceding crops } & \multicolumn{2}{c|}{$\begin{array}{c}\text { Maize yield } \\
\text { (ton/fed) }\end{array}$} & \multicolumn{2}{c|}{$\begin{array}{c}\text { Soybean yield } \\
\text { (ton/fed) }\end{array}$} & $\begin{array}{c}\text { Fahl berseem } \\
\text { (ton/fed) }\end{array}$ \\
\cline { 2 - 7 } & Grain & Straw & Seed & Straw & Fresh forage \\
\hline Maize & \multicolumn{5}{|c|}{$2015 / 2016$ season } \\
\hline Maize/Fahl berseem & 3.219 & 3.887 & - & - & - \\
\hline Soybean & 3.227 & 4.007 & - & - & 6.600 \\
\hline Soybean/Fahl berseem & - & - & 1.316 & 2.742 & - \\
\hline & - & - & 1.303 & 2.722 & 6.950 \\
\hline Maize & & & $2016 / 2017$ & season & \\
\hline Maize/Fahl berseem & 3.155 & 3.850 & - & - & - \\
\hline Soybean & 3.205 & 3.958 & - & - & 7.280 \\
\hline Soybean/Fahl berseem & - & - & 1.300 & 2.680 & - \\
\hline
\end{tabular}

III. Data recorded on sugar beet characters:

a. Growth characters:

At harvest, a random sample of five guarded plants in each subplot was taken. Samples were carried immediately to laboratory where roots were washed to remove the soil particles and then plants were separated to tops and roots. The following characters were estimated:

1. Number of leaves/plant.

2. Root length $(\mathrm{cm})$.

3. Root diameter $(\mathrm{cm})$.

4. Root fresh weight / plant (g).

5. Top fresh weight / plant (g).

b. Sugar beet yields/fed:

At harvest time, plants of whole sub plot were harvested then separated in to tops and roots and weighed and then converted to estimate:

1. Root yield/fed (ton).

2. Top yield/fed (ton).

3. Gross sugar yield/fed (ton) $=$ root yield ton/fed $\times$ sucrose $\%$

\section{c. Chemical analysis of sugar beet:}

Samples of $26 \mathrm{~g}$ fresh root weight were taken for each treatment to determine:
1. Total soluble solids \% (TSS\%) measured by Refractometer according to A.O.A.C. (1990).

2. Sucrose (\%) was estimated according to methods described by Le - Docte (1927).

3. Apparent purity $\%$ was determined as ratio of sucrose \% divided by TSS\% of roots as method outlined by Carruthers and Oldfield (1960).

\section{Evaluation of different crop sequences:}

a. Biological evaluation:

Cereal units CUs were calculated for each individual crop, summer season crops, catch crop, winter season crop and whole year structure (summer+ catch + winter crops). According to Brockhaus (1962) each $100 \mathrm{~kg}$ of grain maize is equal to $1.0 \mathrm{CU}$ and $100 \mathrm{~kg}$ of straw maize equal to $0.10 \mathrm{CU}$. For soybean $100 \mathrm{~kg}$ of seed and straw were equal 1.5 and $0.25 \mathrm{CU}$, respectively. $\quad 100 \mathrm{~kg}$ of fahl berseem equal to $0.14 \mathrm{CU}$. Furthermore, $100 \mathrm{~kg}$ of top and root of sugar beet equal 0.10 and $0.25 \mathrm{CU}$, respectively.

b. Economic evaluation:

Since it was possible to produce more 
than one crop within a year, total and net return for whole year were calculated from different crops within the year. Price and cost (fixed and variable) were presented by (Bulletin of Statistical Cost Production and Net Return, 2015 and 2016) Ministry of Agric., Agric. Econ. Inst., Egypt.

Statistical analysis: Mean data collected were significantly analyzed according to Gomez and Gomez (1984). Treatment means were compared using (L.S.D test at $5 \%$ ) as outlined by Waller and Duncan (1969). All statistical analysis performed using analysis of variance technique by Mstat-computer 1990.

\section{RESULTS AND DISCUSSION}

1. The effect of mono and di preceding crops on soil fertility:

Chemical analysis of experimental soil showed that it is rich with organic matter and available NPK content, but very poor in its content of boron Table (4). Unavailability of boron may be due to high $\mathrm{pH}$ or absorption boron on organic matter. Boron (B) availability is reduced when soil $\mathrm{pH}$ increases above 7.5 (McKenzie, 2015).
Data in Table (4) clearly indicated that the legume as a preceding crop can improve soil content of organic matter, available NPK as well as Boron element. Chemical soil analysis before growing sugar beet indicated that di preceding crop soybean/fahl berseem produced the highest values of these elements and organic matter content. Di preceding crops enhanced the soil organic matter by (3.32 and $2.41 \%)$ than mono preceding crop. Where soil organic matter was increased by retention of residues and $\mathrm{N}_{2}$ fixing (Shafi et al., 2010). Likewise, growing fahl berseem as catch crop after maize or soybean increased soil content of available $N$ (7.85 and 1.20\%), P (2.75 and $2.00 \%), K(0.70$ and $4.83 \%)$ and $B$ (59.36 and 20.56\%) compared with maize and soybean (as a mono preceding crop), as average of the both seasons, respectively. These indicated that nodule bacteria on the root system of legume crops can fix nitrogen $\left(\mathrm{N}_{2}\right)$ from the atmosphere and concentrate and activate phosphorus $(P)$ and potassium $(K)$ in the sub-soil (Kadam et al., 2010 and Vidyavathi et al., 2012 Pokhrel and Pokhrel, 2013). Also, legumes fix the atmospheric nitrogen and facilitate soil nutrients' circulation (Stagnari, 2017).

Table (4). The effect of mono and di preceding crops on soil content of O.M., available NPK and Boron ( $\mathrm{mg} / \mathrm{kg}$ soil) before sugar beet planting in both seasons.

\begin{tabular}{lccccc}
\hline Trait & Preceding crop & Maize & $\begin{array}{c}\text { Maize Ifahl } \\
\text { berseem }\end{array}$ & Soybean & $\begin{array}{c}\text { Soybean } / f a h l \\
\text { berseem }\end{array}$ \\
\hline O. M. & $1^{\text {st }}$ season & 1.735 & 1.764 & 1.797 & 1.812 \\
$(\mathrm{mg} / \mathrm{kg})$ & $2^{\text {nd }}$ season & 1.638 & 1.721 & 1.682 & 1.752 \\
Mean & & 1.687 & 1.743 & 1.740 & 1.782 \\
\hline Available N & $1^{\text {st }}$ season & 109.03 & 110.86 & 111.48 & 112.66 \\
(mg/kg) & $2^{\text {nd }}$ season & 95.43 & 109.64 & 110.13 & 110.34 \\
Mean & & 102.23 & 110.25 & 110.81 & 111.50 \\
\hline Available P & $1^{\text {st }}$ season & 26.11 & 27.20 & 28.39 & 29.00 \\
(mg/kg) & $2^{\text {nd }}$ season & 25.54 & 25.88 & 26.46 & 26.93 \\
Mean & & 25.83 & 26.54 & 27.42 & 27.97 \\
\hline Available K & $1^{\text {st }}$ season & 536.83 & 551.74 & 544.29 & 581.57 \\
$(\mathrm{mg} / \mathrm{kg})$ & $2^{\text {nd }}$ season & 529.38 & 521.92 & 536.83 & 551.74 \\
Mean & & 533.11 & 536.83 & 540.56 & 566.66 \\
\hline Boron (B) & $1^{\text {st }}$ season & 0.186 & 0.329 & 0.327 & 0.422 \\
(mg/kg) & $2^{\text {nd }}$ season & 0.187 & 0.266 & 0.314 & 0.352 \\
Mean & & 0.187 & 0.298 & 0.321 & 0.387 \\
\hline
\end{tabular}


2. The effect of mono and di preceding crops on sugar beet:

\subsection{Growth and yield component} characters of sugar beet:

Preceding crops had significant effect on growth and yield components of sugar beet, i.e., no. of leaves/plant, root length and diameter as well as fresh weights of root and top/plant in both seasons, as shown in Table (5). The highest values of these traits were achieved when sugar beet was grown after soybean/fahl berseem followed by soybean then fahl berseem preceded by maize as preceding crops, whereas, the lowest values were gained following maize. This increase was not significant between soybean/fahl berseem and soybean as preceding crops for all sugar beet growth and yield component characters in both seasons and this increase also was not significant between soybean/fahl berseem and maize Ifahl berseem for no. of leaves/plant in both seasons and root length in the second season. The previous results may be due to residual effect of legume crops (soybean and fahl berseem as preceding crops) in improving soil porosity and structure (McCallum et al., 2004) and increasing the available $\mathrm{N}$ supply for the following crops (Das et al., 2010). Legumes fix the atmospheric nitrogen and facilitate soil nutrients' circulation (Stagnari, 2017).

Fixing atmospheric nitrogen contributes to build up plant organs, encouraging meristmic activity so that, no. of leaves, root length and diameter, fresh weight of root/plant increased. These results are in accordance with those obtained by Sims (2007), El-Mallah (2008) and Ibrahim (2018).

Table (5): The effect of mono and di preceding crops on growth and yield components of sugar beet in 2015/2016 and 2016/2017.

\begin{tabular}{|c|c|c|c|c|c|}
\hline \multirow{2}{*}{$\begin{array}{c}\text { Trait } \\
\text { Treatment }\end{array}$} & \multirow{2}{*}{$\begin{array}{l}\text { No.of } \\
\text { leaves/ } \\
\text { plant }\end{array}$} & \multicolumn{2}{|c|}{ Root } & \multicolumn{2}{|c|}{ Fresh weight /plant } \\
\hline & & $\begin{array}{l}\text { length } \\
\text { (cm) }\end{array}$ & $\begin{array}{l}\text { diameter } \\
\text { (cm) }\end{array}$ & $\begin{array}{c}\text { Root } \\
\text { (g) }\end{array}$ & $\begin{array}{l}\text { Top } \\
\text { (g) }\end{array}$ \\
\hline Preceding crops & \multicolumn{5}{|c|}{$2015 / 2016$ season } \\
\hline Maize & 26.39 & 36.83 & 9.83 & 804.78 & 354.38 \\
\hline Maize/fahl. & 30.16 & 40.00 & 11.88 & 847.53 & 414.29 \\
\hline Soybean & 31.50 & 42.11 & 12.39 & 914.06 & 428.02 \\
\hline Soybean/ fahl. & 32.97 & 42.67 & 12.91 & 941.92 & 472.00 \\
\hline LSD at 0.05 & 3.15 & 1.46 & 1.02 & 28.39 & 27.76 \\
\hline Preceding crops & \multicolumn{5}{|c|}{$2016 / 2017$ season } \\
\hline Maize & 24.12 & 33.59 & 9.83 & 796.97 & 309.21 \\
\hline Maizel fahl. & 26.11 & 35.11 & 10.78 & 816.08 & 345.50 \\
\hline Soybean & 29.83 & 37.17 & 12.27 & 874.61 & 447.37 \\
\hline Soybean/ fahl. & 30.72 & 39.78 & 13.01 & 912.12 & 469.93 \\
\hline LSD at 0.05 & 5.16 & 5.61 & 2.00 & 19.09 & 23.87 \\
\hline
\end{tabular}

fahl.= fahl berseem 


\subsection{Yield of sugar beet:}

Root, top and sugar yields/fed of sugar beet were significantly affected by the position of sugar beet after different preceding crops in both seasons (Table 6). The trend of these traits behaved the same as growth and yield component characters of sugar beet. The highest root, top and sugar yields were achieved after soybean/fahl berseem (33.48, 16.77 and 5.24 and 31.99, 14.59, 4.76 ton/fed), in first and second season, and were the same yields obtained after soybean (32.54, 15.32, 5.17 and 30.65, 14.07, 4.59 ton/fed) with an ignored differences, respectively, in 2016 and 2017 seasons. Growing fahl berseem as catch crop increased root yield by (6.18 and 5.78\%) after maize and (2.89 and 4.37\%) after soybean, while sugar yield increased by (2.11 and 4.03\%) and (1.35 and 3.70\%) following maize and soybean, respectively, in 2015/2016 and 2016/2017 seasons.

The increase in top, root and sugar yields/fed could be attributed to positive residual effect of leguminous crops on yield components of sugar beet. This result is in accordance with those obtained by Sims (2007), Maareg et al. (2005), El-Mallah (2008) and Ibrahim (2018). Legumes in intensive agriculture have proven to increase yields of subsequent crops (Abou-Kerisha et al., 2008, Peoples et al., 2009 and Abdel Galil et al., 2015).

\subsection{Quality of sugar beet:}

Data presented in Table (6) clearly showed that some chemical analysis of sugar beet juice was significantly influenced by preceding crop in both seasons. The highest values of TSS\%, sucrose $\%$ and purity $\%$ were detected when sugar beet sowing after maize, whereas the lowest values were achieved following soybean/fahl berseem in both seasons. These results may be due to the decrease in root weight and diameter, after maize, which leads to decreasing tissue water content and non-sucrose substance such as proteins and alpha amino nitrogen, which consequently increased sucrose \% content in sugar beet roots. These results are in accordance with those obtained by Sims (2007) and Ibrahim (2018).

Table (6): The effect of mono and di preceding crops on yield and its components and quality of sugar beet in 2015/2016 and 2016/2017 seasons.

\begin{tabular}{|c|c|c|c|c|c|c|}
\hline \multirow{2}{*}{ Treatment } & \multicolumn{3}{|c|}{ Yield (Ton/ fed) } & \multirow{2}{*}{$\begin{array}{c}\text { TSS } \\
\%\end{array}$} & \multirow{2}{*}{$\begin{array}{c}\text { Sucrose } \\
\%\end{array}$} & \multirow{2}{*}{$\begin{array}{c}\text { Purity } \\
\%\end{array}$} \\
\hline & Root & Top & Sugar & & & \\
\hline Preceding crops & \multicolumn{6}{|c|}{ 2015/2016 season } \\
\hline Maize & 28.16 & 13.08 & 4.75 & 20.41 & 16.84 & 82.49 \\
\hline Maize/fahl. & 29.90 & 14.54 & 4.85 & 20.00 & 16.17 & 80.83 \\
\hline Soybean & 32.54 & 15.32 & 5.17 & 19.73 & 15.85 & 80.33 \\
\hline Soybean/ fahl. & 33.48 & 16.77 & 5.24 & 19.48 & 15.62 & 80.20 \\
\hline LSD at 0.05 & 2.17 & 2.19 & 0.30 & 0.90 & 0.45 & 1.22 \\
\hline Preceding crops & \multicolumn{6}{|c|}{$2016 / 2017$ season } \\
\hline Maize & 27.34 & 11.37 & 4.47 & 20.94 & 16.32 & 77.90 \\
\hline Maize/fahl. & 28.92 & 12.93 & 4.56 & 20.72 & 16.06 & 77.49 \\
\hline Soybean & 30.65 & 14.07 & 4.59 & 19.33 & 14.96 & 77.36 \\
\hline Soybean/ fahl. & 31.99 & 14.59 & 4.76 & 19.39 & 14.85 & 76.59 \\
\hline LSD at 0.05 & 1.98 & 0.85 & 0.24 & 1.15 & 0.50 & 1.16 \\
\hline
\end{tabular}

fahl.= fahl berseem 
3. The effect of foliar application of boron on sugar beet:

\subsection{Growth and yield components of sugar beet:}

It is clear from the data in Table (7) that foliar application of boron affected significantly growth and yield components of sugar beet i.e. root length and diameter and fresh weight of root and top/plant in both seasons except, number of leaves/plant in the second season. Generally increasing boron concentration from 0 up to $0.20 \mathrm{~g} \mathrm{B/L}$ increased sugar beet growth and yield component characters. These results may be attribute to role of boron activity in hormonal balance and enzyme activity which responsible for facilitate carbohydrate and cell division, boron promotes the stability and rigidity of cell wall structure and therefore, supports the shape and strength of the plant cell (Brown et al, 2002). Similar results were obtained by Abbas et al. (2014), Dewedar et al. (2015), Abdel-Motagally (2015) and Nemeata Alla et al. (2016).

\subsection{Yields of sugar beet:}

Foliar application of boron significantly increased top, root and sugar yields/fed by increasing boron concentration from 0 to 0.10 and $0.20 \mathrm{~g}$ $B / L$ as shown in Table (8). Boron application at $0.20 \mathrm{~g} / \mathrm{L}\left(\mathrm{B}_{3}\right)$ significantly increased root and sugar yield as compared with $B_{1}$ and $B_{2}$ by (11.56 and $6.39 \%$ for root yield and 23.06 and $12.35 \%$ for sugar yield) in the first season and (13.47 and $6.99 \%$ and 22.06 and $10.89 \%$ ) in the second season. Without boron growth and sugar beet yield were depressed (Cooke and Scott, 1993).

The increase in sugar beet root yield could be attributed to role of boron in formation new cells in meristems, which increase root length, root diameter and root weight, consequently increase root yield. While increasing sugar yield as boron concentration increased could be due to increase the rate of transport of sugars which are produced by photosynthesis in mature plant leaves to growing regions Allen et al. (2007). These results are in accordance with those obtained by Abbas et al. (2014), Dewedar et al. (2015) and Nemeata Alla et al. (2016).

Table (7): The effect of boron element foliar application on growth and yield components of sugar beet in 2015/2016 and 2016/2017 seasons.

\begin{tabular}{|c|c|c|c|c|c|}
\hline \multirow[b]{2}{*}{ Treatment } & \multirow{2}{*}{$\begin{array}{c}\text { No.of } \\
\text { leaves/ } \\
\text { plant }\end{array}$} & \multicolumn{2}{|c|}{ Root } & \multicolumn{2}{|c|}{ Fresh weight /plant } \\
\hline & & $\begin{array}{l}\text { length } \\
\text { (cm) }\end{array}$ & $\begin{array}{l}\text { diameter } \\
\text { (cm) }\end{array}$ & $\begin{array}{c}\text { Root } \\
\text { (g) }\end{array}$ & $\begin{array}{c}\text { Top } \\
\text { (g) }\end{array}$ \\
\hline & \multicolumn{5}{|c|}{ 2015/2016 season } \\
\hline $\mathrm{B}_{1}$ at 0 (control) & 27.29 & 37.88 & 11.13 & 833.22 & 390.43 \\
\hline $\mathrm{B}_{2}$ at $0.10 \mathrm{~g} / \mathrm{L}$ & 30.77 & 41.04 & 11.50 & 868.50 & 412.52 \\
\hline $\mathrm{B}_{3}$ at $0.20 \mathrm{~g} / \mathrm{L}$ & 32.71 & 42.29 & 12.63 & 929.50 & 448.56 \\
\hline \multirow[t]{2}{*}{ LSD at 0.05} & 1.78 & 1.13 & 0.67 & 23.51 & 21.00 \\
\hline & \multicolumn{5}{|c|}{ 2016/2017 season } \\
\hline $\mathrm{B}_{1}$ at 0 (control) & 26.63 & 34.92 & 10.60 & 811.34 & 343.26 \\
\hline $\mathrm{B}_{2}$ at $0.10 \mathrm{~g} / \mathrm{L}$ & 27.75 & 35.98 & 11.45 & 848.45 & 410.42 \\
\hline $\mathrm{B}_{3}$ at $0.20 \mathrm{~g} / \mathrm{L}$ & 28.71 & 38.33 & 12.36 & 890.06 & 425.33 \\
\hline LSD at 0.05 & N.S & 2.66 & 0.83 & 12.59 & 18.54 \\
\hline
\end{tabular}




\subsection{Quality of sugar beet:}

Data listed in Table (8) indicated that boron foliar application caused significant increase in TSS \%, sucrose \% and purity $\%$ in both seasons, except purity \% in first season. Application of $0.20 \mathrm{~g} \mathrm{~B} / \mathrm{L}\left(\mathrm{B}_{3}\right)$ gave the highest values of these traits. The increase in sucrose $\%$ as boron concentration increased from $B_{1}$ to $B_{2}$ and $B_{3}$ were $(10.21$ and $5.55 \%)$ in the first season whereas, these increases were $(7.62$ and $3.47 \%)$ in the second season. The previous results might be attributed to the balance in the sodium uptake and nitrogen consumption caused by boron. Similar results were reported by Abbas et al. (2014), Abdel-Motagally 2015 and Dewedar et al. (2015).

4. The effect of the Interaction between mono and di preceding crops and boron element foliar application on sugar beet traits:

Data in Table (9) cleared that most sugar beet traits were affected by the interaction between mono and di preceding crops and foliar application of boron, except root length and purity $\%$ in both seasons, root diameter and top yield (ton/fed) in the first season and number of leaves/plant in the second season. Combination between soybean/fahl berseem succeeding sugar beet and foliar application $B_{3}(0.20 \mathrm{~g} \mathrm{B/L})$ led to the highest values of the most traits, except root weight/plant in first season no. of leaves/ plant in second season and TSS\% and sucrose \% in both seasons. The highest values of quality traits observed when sowing sugar beet after maize and boron application at $0.20 \mathrm{~g} / \mathrm{L}$. On the other hand, growing sugar beet after maize without boron $\left(B_{1}\right)$ achieved lowest values in both seasons, except quality traits of sugar beet. That is indicated that the role of double legume as preceding crops of sugar beet and boron application in increased cell division, merstimic activity and building up plant organs, which led to superiority of root and sugar yields. These results are in accordance with those obtained by ElMallah (2008), Abbas et al. (2014), Dewedar et al. (2015) and Ibrahim (2018).

Table (8): The effect of boron element foliar application on yield and quality of sugar beet in 2015/2016 and 2016/2017 seasons.

\begin{tabular}{|c|c|c|c|c|c|c|}
\hline \multirow{2}{*}{ Treatment } & \multicolumn{3}{|c|}{ Yield (Ton/ fed) } & \multirow{2}{*}{$\begin{array}{c}\text { TSS } \\
\%\end{array}$} & \multirow{2}{*}{$\begin{array}{c}\text { Sucrose } \\
\%\end{array}$} & \multirow{2}{*}{$\begin{array}{c}\text { Purity } \\
\%\end{array}$} \\
\hline & Root & Top & Sugar & & & \\
\hline & \multicolumn{6}{|c|}{ 2015/2016 season } \\
\hline $\mathrm{B}_{1}$ at $\mathrm{O}$ (control) & 29.41 & 13.72 & 4.51 & 19.11 & 15.37 & 80.43 \\
\hline $\mathrm{B}_{2}$ at $0.10 \mathrm{~g} / \mathrm{L}$ & 30.84 & 15.20 & 4.94 & 19.80 & 16.05 & 81.04 \\
\hline $\mathrm{B}_{3}$ at $0.20 \mathrm{~g} / \mathrm{L}$ & 32.81 & 15.87 & 5.55 & 20.81 & 16.94 & 81.42 \\
\hline \multirow[t]{2}{*}{ LSD at 0.05} & 1.24 & 0.98 & 0.20 & 1.06 & 0.33 & N.S \\
\hline & \multicolumn{6}{|c|}{$2016 / 2017$ season } \\
\hline $\mathrm{B}_{1}$ at 0 (control) & 27.91 & 11.70 & 4.17 & 19.54 & 14.97 & 76.61 \\
\hline$B_{2}$ at $0.10 \mathrm{~g} / \mathrm{L}$ & 29.60 & 13.86 & 4.59 & 20.11 & 15.57 & 77.40 \\
\hline $\mathrm{B}_{3}$ at $0.20 \mathrm{~g} / \mathrm{L}$ & 31.67 & 14.16 & 5.09 & 20.65 & 16.11 & 78.00 \\
\hline LSD at 0.05 & 0.55 & 0.59 & 0.07 & 0.50 & 0.26 & 0.95 \\
\hline
\end{tabular}


Table (9): The effect of interaction between mono and di preceding crops and boron application on sugar beet traits in 2015/2016 and 2016/2017 seasons.

\begin{tabular}{|c|c|c|c|c|c|c|c|c|c|c|}
\hline \multicolumn{2}{|l|}{ Trait } & \multirow{2}{*}{$\begin{array}{l}\text { No of } \\
\text { leaves } \\
\text { Iplant }\end{array}$} & \multirow{2}{*}{$\begin{array}{l}\text { Root } \\
\text { diam. } \\
\text { (cm) }\end{array}$} & \multicolumn{2}{|c|}{$\begin{array}{l}\text { Fresh weight of } \\
\text { plant }\end{array}$} & \multicolumn{3}{|c|}{$\begin{array}{c}\text { Yield } \\
\text { (Ton/ fed) }\end{array}$} & \multirow{2}{*}{$\begin{array}{l}\text { TSS } \\
(\%)\end{array}$} & \multirow{2}{*}{$\begin{array}{c}\text { Sucrose } \\
\text { (\%) }\end{array}$} \\
\hline \multicolumn{2}{|c|}{$\begin{array}{l}\text { Preceding } \\
\text { crop }\end{array}$} & & & $\begin{array}{l}\text { Root } \\
\text { (g) }\end{array}$ & $\begin{array}{l}\text { Top } \\
\text { (g) }\end{array}$ & Root & Top & sugar & & \\
\hline \multicolumn{2}{|c|}{ Boron } & \multicolumn{9}{|c|}{$2015 / 2016$ season } \\
\hline \multirow{3}{*}{ Maize } & $\mathrm{B}_{1}$ & 22.67 & 9.93 & 762.00 & 318.82 & 26.38 & 11.57 & 4.25 & 19.43 & 16.11 \\
\hline & $\mathrm{B}_{2}$ & 27.00 & 8.93 & 810.00 & 355.33 & 28.26 & 13.65 & 4.83 & 20.81 & 17.10 \\
\hline & $\mathrm{B}_{3}$ & 29.50 & 10.63 & 842.33 & 389.00 & 29.83 & 14.01 & 5.16 & 21.00 & 17.30 \\
\hline \multirow{4}{*}{$\begin{array}{l}\text { Maize } \\
\text { /Fahl. }\end{array}$} & $\mathrm{B}_{1}$ & 26.33 & 10.97 & 817.31 & 394.85 & 28.28 & 13.64 & 4.37 & 19.50 & 15.45 \\
\hline & $\mathrm{B}_{2}$ & 30.33 & 11.33 & 828.93 & 403.25 & 29.23 & 14.84 & 4.62 & 19.50 & 15.82 \\
\hline & $\mathrm{B}_{3}$ & 33.83 & 13.35 & 896.36 & 444.76 & 32.20 & 15.13 & 5.55 & 21.00 & 17.25 \\
\hline & $\mathrm{B}_{1}$ & 28.67 & 11.32 & 842.42 & 395.37 & 30.74 & 14.17 & 4.63 & 18.80 & 15.07 \\
\hline \multirow[t]{2}{*}{ Soybean } & $\mathrm{B}_{2}$ & 32.50 & 12.82 & 906.54 & 421.87 & 32.62 & 15.36 & 5.22 & 19.90 & 15.99 \\
\hline & $\mathbf{B}_{3}$ & 33.33 & 13.05 & 993.21 & 466.81 & 34.25 & 16.44 & 5.65 & 20.50 & 16.50 \\
\hline \multirow{3}{*}{$\begin{array}{l}\text { Soybean } \\
\text { IFahl. }\end{array}$} & $\mathrm{B}_{1}$ & 31.50 & 12.30 & 911.13 & 452.68 & 32.24 & 15.50 & 4.79 & 18.70 & 14.85 \\
\hline & $\mathbf{B}_{2}$ & 33.23 & 12.93 & 928.54 & 469.64 & 33.26 & 16.94 & 5.09 & 19.00 & 15.30 \\
\hline & $\mathbf{B}_{3}$ & 34.17 & 13.50 & 986.09 & 493.67 & 34.95 & 17.88 & 5.84 & 20.73 & 16.72 \\
\hline \multicolumn{2}{|c|}{ LSD at 0.05} & 2.60 & & 34.28 & 30.62 & 1.81 & N.S & 0.29 & 0.68 & 0.48 \\
\hline \multirow{4}{*}{ Maize } & & \multicolumn{9}{|c|}{ 2016/2017 season } \\
\hline & $\mathrm{B}_{1}$ & 21.68 & 9.28 & 779.59 & 290.91 & 25.74 & 9.98 & 3.95 & 20.00 & 15.36 \\
\hline & $\mathbf{B}_{2}$ & 23.83 & 10.22 & 795.16 & 305.12 & 27.60 & 11.74 & 4.58 & 21.33 & 16.61 \\
\hline & $\mathbf{B}_{3}$ & 26.83 & 9.98 & 816.15 & 331.60 & 28.68 & 12.40 & 4.87 & 21.50 & 16.99 \\
\hline \multirow{3}{*}{$\begin{array}{l}\text { Maize } \\
\text { IFahl. }\end{array}$} & $\mathrm{B}_{1}$ & 22.83 & 9.75 & 776.05 & 300.91 & 27.22 & 10.73 & 4.21 & 20.33 & 15.48 \\
\hline & $\mathrm{B}_{2}$ & 27.50 & 10.93 & 808.12 & 370.52 & 28.82 & 14.19 & 4.65 & 20.83 & 16.12 \\
\hline & $\mathrm{B}_{3}$ & 28.00 & 11.67 & 864.07 & 365.07 & 30.73 & 13.87 & 5.10 & 21.00 & 16.58 \\
\hline \multirow{3}{*}{ Soybean } & $\mathrm{B}_{1}$ & 28.83 & 10.80 & 809.65 & 383.57 & 28.21 & 12.79 & 4.12 & 18.83 & 14.59 \\
\hline & $\mathrm{B}_{2}$ & 29.17 & 12.22 & 894.72 & 469.33 & 31.00 & 14.54 & 4.55 & 19.00 & 14.67 \\
\hline & $\mathrm{B}_{3}$ & 31.50 & 13.80 & 919.47 & 489.20 & 32.75 & 14.88 & 5.11 & 20.17 & 15.61 \\
\hline \multirow{3}{*}{$\begin{array}{c}\text { Soybean } \\
\text { IFahl. }\end{array}$} & $\mathrm{B}_{1}$ & 30.50 & 12.58 & 880.05 & 397.65 & 30.47 & 13.32 & 4.40 & 19.00 & 14.44 \\
\hline & $\mathrm{B}_{2}$ & 30.83 & 12.45 & 895.78 & 496.72 & 30.97 & 14.96 & 4.60 & 19.27 & 14.86 \\
\hline & $\mathrm{B}_{3}$ & 30.83 & 14.00 & 960.53 & 515.43 & 34.52 & 15.50 & 5.27 & 19.91 & 15.26 \\
\hline \multicolumn{2}{|c|}{ LSD at 0.05} & N.S & 1.22 & 18.36 & 27.03 & 0.80 & 0.86 & 0.17 & 0.56 & 0.37 \\
\hline
\end{tabular}

5. The effect of different mono and di preceding crops on:

5.1. Biological evaluation:

Cereal units for each individual crop, preceding crops, catch crop, sugar beet crop and whole year structure (preceding + catch + sugar beet) are presented in
Table (10). The results showed that the lowest value of cereal units (111.67 CUs/fed) were achieved by sowing sugar beet after maize without foliar application of boron (as mono preceding crop) as average of the both growing seasons. 
Zahera M. Attia, et al.,

Table (10): Total cereal units (CUs), total return and net return of summer crops, catch crop and sugar beet (whole sequence) in 2015/2016 and 2016/2017 seasons.

\begin{tabular}{|c|c|c|c|c|c|c|}
\hline \multicolumn{2}{|c|}{$\begin{array}{l}\text { Preceding crops } x \\
\text { Boron application }\end{array}$} & $\begin{array}{c}\text { CUs of } \\
\text { preceding + }\end{array}$ & $\begin{array}{l}\text { CUs of } \\
\text { sugar }\end{array}$ & $\begin{array}{c}\text { Total } \\
\text { CUs/fed }\end{array}$ & $\begin{array}{l}\text { Total return } \\
\text { (L.E./fed) }\end{array}$ & $\begin{array}{l}\text { Net } \\
\text { return }\end{array}$ \\
\hline \multirow{3}{*}{ Maize } & $\mathrm{B}_{1}$ & \multirow{3}{*}{35.74} & 75.93 & 111.67 & 18412 & 6281 \\
\hline & $\mathrm{B}_{2}$ & & 82.52 & 118.26 & 19241 & 7010 \\
\hline & $\mathrm{B}_{3}$ & & 86.34 & 122.08 & 19776 & 7445 \\
\hline \multirow{3}{*}{$\begin{array}{l}\text { Maize/fahl } \\
\text { berseem }\end{array}$} & $\mathrm{B}_{1}$ & \multirow{3}{*}{$36.15+9.72$} & 81.56 & 127.43 & 21333 & 8381 \\
\hline & $B_{2}$ & & 87.08 & 132.95 & 21963 & 8911 \\
\hline & $B_{3}$ & & 93.16 & 139.03 & 22887 & 9735 \\
\hline \multirow{3}{*}{ Soybean } & $B_{1}$ & \multirow{3}{*}{26.40} & 87.17 & 113.57 & 18100 & 7650 \\
\hline & $B_{2}$ & & 94.48 & 120.88 & 19078 & 8528 \\
\hline & $\mathrm{B}_{3}$ & & 99.41 & 125.81 & 19763 & 9113 \\
\hline \multirow{3}{*}{$\begin{array}{c}\text { Soybean Ifahl } \\
\text { berseem }\end{array}$} & $B_{1}$ & \multirow{3}{*}{$26.13+10.21$} & 92.80 & 129.14 & 21002 & 9731 \\
\hline & $\mathrm{B}_{2}$ & & 96.24 & 132.58 & 21387 & 10016 \\
\hline & $B_{3}$ & & 103.53 & 139.87 & 22426 & 10955 \\
\hline
\end{tabular}

Price L.E. per ton was: grain maize $=2300$, seed soybean $=4275$, straw maize $=136$, straw soybean $=$ 180 , fahl berseem $=304$, root and top of sugar beet were 379 and 63 , respectively.

Costs of different crops (fixed and variable) L.E./fed were maize $=5278$, soybean $=3597$ and sugar beet $=6853$, while variable cost of fahl berseem $=821$.

On the contrary, the highest values (139.87 CUs/fed) was obtained when soybean/fahl berseem preceded sugar beet, followed by $139.03 \mathrm{CUs/fed} \mathrm{after}$ maize/fahl berseem (as di preceding crops) and boron applied at $0.20 \mathrm{~g} / \mathrm{L}$. Growing fahl berseem as catch crop after maize and soybean increased total cereal units by 13.46 and $11.47 \%$ as average of both seasons compared with the other once. Intensive crop sequence increased total production CUs/fed compared with maize and soybean as preceding crops. The results are in agreement with those obtained by El-Mehy et al. (2016) and Zohry et al. (2017).

\subsection{Economic evaluation:}

Economic evaluation behaved the same trend as biological evaluation as shown in Table (10). Since, the lowest and highest total and net return were achieved with mono and di preceding crops, respectively. Tri crop sequence (maize/fahl berseem/sugar beet) was gained the highest values of total return/fed (L.E. 22887), while (soybean/ fahl berseem/sugar beet) produced the highest net return (L.E. 10995) with foliar application of boron at $0.20 \mathrm{~g} / \mathrm{L}$, respectively, as average of both seasons. The variation in trend of total and net return may be due to differences in market price and costs of maize and soybean. However, growing fahl berseem, as catch crop, following maize and soybean increased net return L.E.Ifed by 33.50 and $24.08 \%$ compared to traditional sequences, as average of both seasons. These results are in agreement with those reported by Abou-Kerisha et al. (2008), Abdel Galil et al. (2015) and ElMehy et al. (2016).

\section{Conclusion}

Under the conditions of Sers EL-Lian area, sowing sugar beet (cv. Gloria) after soybean/fahl berseem and foliar application of boron at $0.20 \mathrm{~g} / \mathrm{L}$ maximizes root and sugar yields of sugar beet as well as net return/fed. Growing di preceding crop, including fahl berseem as catch crop, enhances the fertility of the soil, increase root and sugar yields of sugar beet as well as increase the net return by (33.50 and $24.08 \%)$ following 
maize and soybean, respectively, compared maize and soybean (as a mono preceding crop).

\section{REFERENCES}

A.O.A.C. (1990). Official methods of Analysis of the Association of official Agricultural Chemists, $15^{\text {th }}$ Ed. Washington, D.C., U.S.A.

Abbas, M. S., M. D. H. Dewdar, E. I. Gaber and H. A. Abd El-Aleem (2014). Impact of boron foliar application on quantity and quality traits of sugar beet (Beta vulgaris L.) in Egypt. Res. J. of Phar., Biol. and Chem. Sci., 5:143-151.

Abdel-Galil, A.M., Sh. I. Abdel-Wahab and T. I. Abdel-Wahab (2015). Effect of some preceded peanut cultivars on wheat yield and agro -economic feasibility under two cropping systems in sandy soil. Sust. Agric. Res., 4 (2):47-56.

Abdel-Motagally, F.M.F. (2015). Effect concentration and spraying time of boron on yield and quality traits of sugar beet grown in newly reclaimed soil conditions. Assiut J. Agric. Sci., 46(6):15-26.

Abou-Kerisha, M. A., R. A. Gadallah and M. M. A. Badr (2008). Effect of preceding and intercropping crops on the productivity of wheat. Minufiya $J$. Agric. Res., 33(3): 709-728.

Allen, V.B., J. David and E.D. Pilbeam (2007). Handbook of plant nutrition (Books in soils, plants and the environment).

Brockhaus, F.A. (1962). ABC der Landwirtschaft, Vol.I VEB, F.A. Brockhaus Verlag, Leipzig.G.D.R. pp 790 (in German).

Brown, P.H., N. Bellaloui, M.A. Wimmer, E.S. Bassil, J. Ruiz, H. Hu, H. Pfeffer, F. Dannel and V. Romheld (2002). Boron in Plant Biology. Plant Biol., 4:205-223.

Bulletin of Statistical Cost Production and Net Return (2015). Summer and Nili Field Crops and Vegetables and
Fruit. Agriculture Statistics and Economic Sector, Ministry of Egyptian Agriculture and Land Reclamation, Part (2), August 2015, Egypt.

Bulletin of Statistical Cost Production and Net Return (2016). Winter Field Crops and Vegetables and Fruit. Agriculture Statistics and Economic Sector, Ministry of Egyptian Agriculture and Land Reclamation, Part (1), February 2016, Egypt.

Carruthers, A. and J.F.T. Oldfield (1960). Methods for the assessment of sugar beet quality. Int. Sug.J., 63 (1):72-74.

Cooke, D.A. and R.K. Scott (1993). The Sugar Beet Crop. Chapman and Hall London, pp. 262-265.

Das, A., D.P. Patel, G. C. Munda and D. K. Ghosh (2010). Effect of organic and inorganic sources of nutrients on yield, nutrient uptake and soil fertility of maize (Zea mays)-mustard (Brassica campestris) cropping systems. Indian J. Agric. Sci., 80(1) : 85- 88.

Dewdar, M. D. H., M. S. Abbas, E. I. Gaber and H. A. Abd El-Aleem (2015). Influence of time addition and rates of boron foliar application on growth, quality and yield traits of sugar beet. Int.J.Curr.Microbiol.App.Sci., 4(2): 231238.

El-Mallah, A.A.A. (2008). Effect of preceding summer crops, nitrogen and potassium fertilization on the productivity of sugar beet (Beta vulgaris L.). Ph.D. Thesis, fac. of Agric. Moshtohor, Benha University, Egypt.

El-Mehy, A. A., S. K. Badr and Z. M. Attia (2016). Growth, yield and yield components of wheat as affected by crop sequences, seeding rates and nitrogen fertilizer levels. Annals of Agric. Sci., Moshtohor, 54 (1):1-14.

Gomez, K.A. and A.A. Gomez (1984). Statistical Procedures for Agricultural Research, Wiley and sons, New York 
Ibrahim, M.E.M. (2018). Effect of preceding summer crops on yield and quality of sugar beet intercropped with faba bean. J. Plant Prod., Mansoura Univ., 9 (1):59-65.

Jackson, M.L. (1973). Soil chemical analysis. Printice Hall, New Delhi, 485 pp.

Kadam, S. R., V. M. Amrustsagar and A. W. Deshpande (2010). Influence of organic nitrogen sources with fulvic acid spray on yield and nutrient uptake of soybean on Inceptisol. J. Soils Crops, 20 (1): 58-63.

Le-Doct, A. (1927). Commercial determination of sugar beet root using the saches - Le-Doct process int. Sug. J., 29:488-492. (C.F. suagr beet Nutrition, 1927. Appl. Sci. Pub. Ltp. London, P. Drycott).

Maareg, M.E., S.F. Tawfik and A.A. Abo El-Ftooh (2005). Effect of preceding crops and nitrogen fertilization on productivity of sugar beet and some economic insect pests infestation in newly reclaimed soil at west Nubaryia region. The $3^{\text {th }}$ Inter. Conf. on IPM role Integrated crop Management and Impact on Envir. and Agric. products, 26-29 Nov., Egypt.

Mc Callum, M.H., J.A. Kirkegaard, T. Green, H.P. Cresswell, S.L. Davies and J.F. Angus (2004). Improved subsoil macro-porosity following perennial pastures. Australian Journal of Experimental Agriculture 44:299-307.

McKenzie, R. (2015). Soil pH is complex, and has different impacts on the availability of different nutrients. https://www.grainews.ca/2015/.../thebroad-basics-of-your-soils-ph-2.

Nemeata Alla, H.E.A., E.A.E. Nemeata Alla and S.S. Zalat (2016). Sugar beet yield and quality as affected by concentration of boron and methanol application. Annals of Agric. Sci., Moshtohor, 54 (1): 25- 34.

Peoples, M.B., I. Brockwell, D.F. Herridge, B. Rochester, R. Alves, S. Urquiaga,
R.M. Boddey, F.D. Dakora, S. Bhattarai, S.L. Maskey, C. Sampet, B. Rerkasem, D.F. Khans, S. HauggaardNielsen and B.S. Jensen (2009). The contributions of nitrogen- fixing crop legumes to the productivity. SYAfBIOSIS. 48:1-17.

Pokhrel, S. and S. Pokhrel (2013). Legumes crop rotation can improve food and nutrition security in Nepal. Agron. J. of Nepal, 3:123-127.

SCC (2017). Sugar Crops Council, Annual Report. Sugar crops and the production of sugar in Egypt, Part VI features of the production and consumption of sugar in Egypt, pp: 115.

Shafi, M., J. Bakht, Attaullah and M. A. Khan (2010). Effect of preceding cropand crop residues on soil $\mathrm{C}$, soil $\mathrm{N}$ and yield of maize. Pak. J. Bot., 42(3): 1651-1664.

Sims, A.L. (2007). Sugar beet production after previous crops of corn, wheat and soybean. Sugar beet Res. Ext. Rept., Coop. Ext. Serv., North Dakota State Univ., 37:110-115.

Stagnari, F., A. Maggio, A. Galieni and M. Pisante (2017). Multiple benefits of legumes for agriculture sustainability: an overview. Chem. Biol. Technol. Agric., 4(2):1-13.

Vidyavathi, D.G. S., H. B. Babalad, N. S. Hebsur, S. K. Gali, S. G. Patil and A. R. Alagawadi (2012). Nutrient status of soil under different nutrient and crop management practices. Karnataka J. Agric. Sci., 25 (2) :193-198.

Waller, R.A. and D.B. Duncan (1969). Abays rule for symmetric multiple comparison problem. Amer. Stat. Assoc. J., 1485-1503.

Zohry, A., S. Ouda, W. Hamd-Alla and E. Shalaby (2017). Evaluation of different crop sequences for wheat and maize in sandy soil. Acta Agric. Slovenica, 109 (2): 383 - 392. 
تأثير المحصول السابق والبيني والرش بالبورون على إنتاجية وجودة بنجر السكر. زهيرة محمد عطية ، أميرة عطية الميهى ، كامل سالم بلر

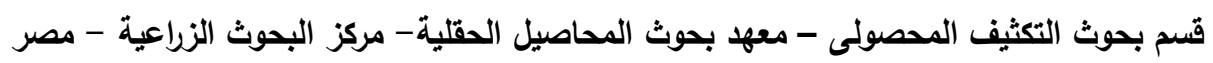
الملخص العربى

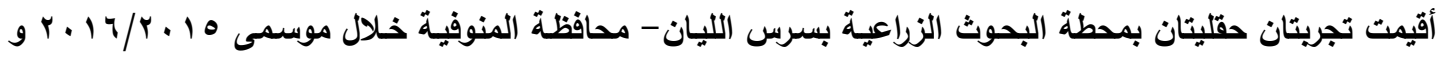

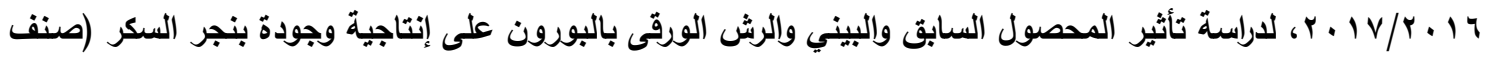

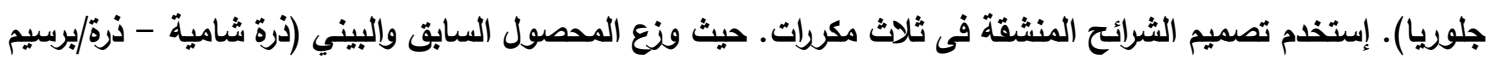

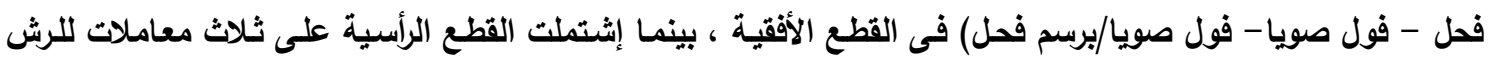

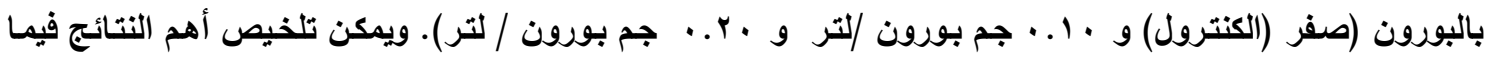
- زاد محتوى التربة من المادة العضوية والنتروجين والفوسفور والبوتاسيوم الميسر وكذلك عنصر البورون (ملليجم/كجم)

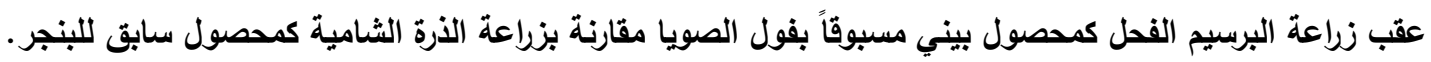

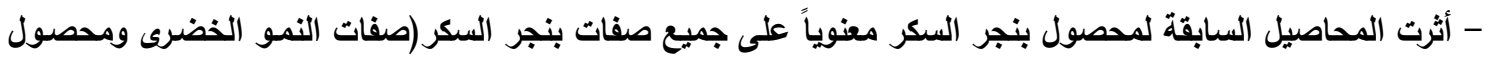

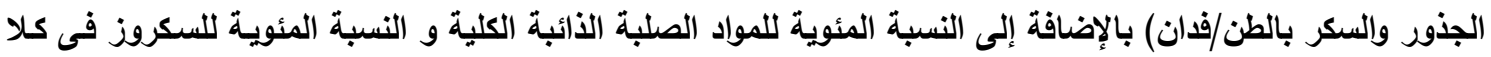
الموسمين، عدا النسبة المئوية للنقاوة فى الموسم الأول.

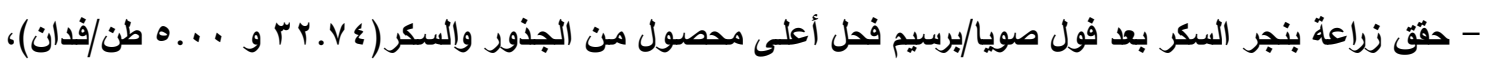
كمتوسط للموسمين، على الترتيب.

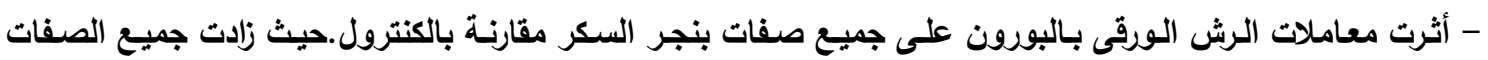

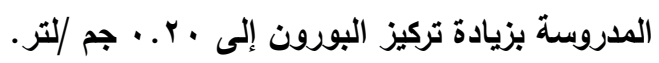

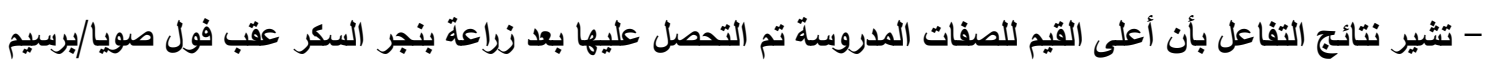

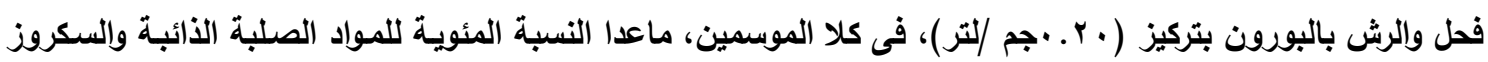

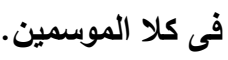
- أدى زراعة البرسيم الفحل كحصول بيني، بعد المحاصيل السابقة، عقب الذرة الثامية وفول الصويا إلى زيادة إجمالى

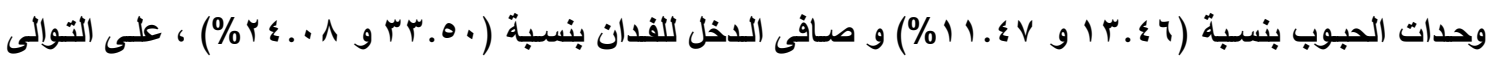

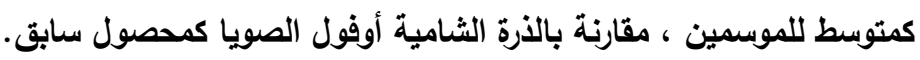

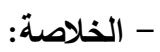

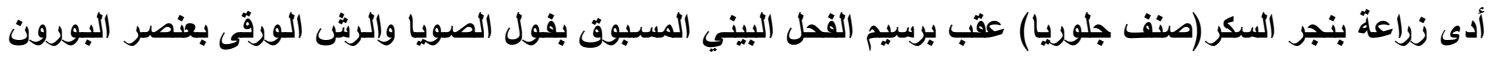

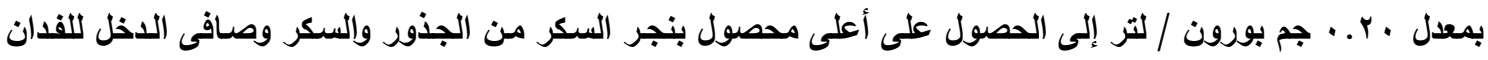

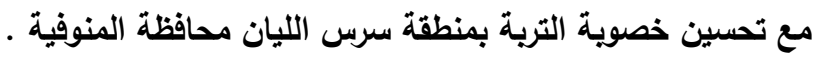

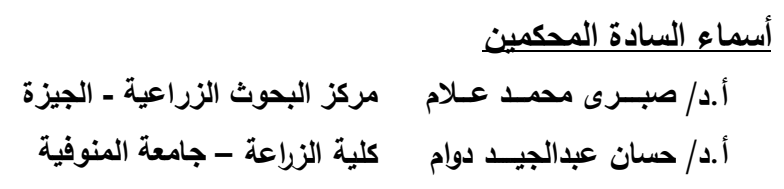


